\title{
Religiosity Values in Entrok Novel by Okky Madasari
}

\author{
Ahmad Wahyudi* \\ Indonesian Language and Literature Education of Graduate School \\ Universitas Negeri Yogyakarta \\ Yogyakarta, Indonesia \\ Ahmadwahyudi2525@gmail.com
}

\author{
Anwar Efendi \\ Indonesian Language and Literature Education of Graduate School \\ Universitas Negeri Yogyakarta \\ Yogyakarta, Indonesia \\ efendianwar@ymail.com
}

\begin{abstract}
This study aims to describe the values of religiosity in the novel entitled Entrok by Okky Madasari. The data source is the novel Entrok, Madasari published by Gramedia Pustaka Utama Jakarta in 2010. Entrok tells about the life of someone named Marni, set in the 1950s in a village called Singget. who holds closely the teachings of her ancestors by asking all the wishes to her ancestors called Gusti Mbah Ibu Bumi Bapa Kuasa. Data were obtained by reading-writing technique. Data were analyzed with qualitative descriptive analysis technique.

The results of this study are the religious values of Marni contained in the novel in terms of: 1) dimension of belief (ideological); 2) dimension of worship (ritualistic); 3) dimension of appreciation (experiential); 4) dimension of religious knowledge (intellectual); and 5) dimension of practice (consequences).
\end{abstract}

\section{Keywords: religious values, Entrok novel}

\section{INTRODUCTION}

Literary work is a work produced by the author with a creative and imaginative processes, because in a literary work the author represents a situation in society as well as the author's ideology into a work with language as its medium. Each literary work is never separated from a circumstance, space and time that includes psychological, sociological, historical, religious and others. Therefore, literary works are often said to be a manifestation of a true story that is poured into the language. This is in agreement with the view of Ajidarma (2010) that the relation of fact and fiction is only a difference in framing a reality or giving meaning to the world and its life or different formats. Just as literary works have the function of dulce et utile, which means they are useful for entertaining and educating readers, literary works also function as a messenger to be channeled by writers.

Literary works provide a beautiful creation and try to channel human beauty and become a container for the delivery of ideas that have been thought and felt by writers (Semi, 1988: 8). This is supported by the opinion of Faruk (2012: 5-6), who states that literary works are also a means of conveying ideas, opinions, or criticism of the environment. In this case, the literary work can provide a picture of life and the conflict that it faces, including the messages to be conveyed, one of which is a moral message in the form of religious values.

If we dig deeper, we will find that all literary works are full of religious values. Atmosuwito (1989:126) says that literature is also a part of religion. As stated by Mangunwijaya (1988) that in the beginning, all forms of literature were religious. Even more clear by Mohammad (1969) that religious literature is a genre of literature that intends to provide answers to the situation based on traditional religious values or also called religious values.

Religiosity is a person's spiritual expression related to the system of beliefs, values, and applicable laws (Mangunwijaya: 1988). Thus religiosity greatly influences human behavior and actions, whether done individually or in groups. Another opinion says that religiosity or diversity includes various sides or dimensions that do not only occur when performing ritual activities (worship), but also occur when someone does other activities that are driven by supernatural powers (Yolanda Hani Putriani: 2015). It can be interpreted that religiosity is how capable individuals carry out aspects of religious beliefs in worship and other social events. From this view, the values of religiosity can be known in several dimensions, namely the dimensions of belief (ideological), dimensions of worship (ritualistic), dimensions of appreciation (experiential), dimensions of religious knowledge (intellectual), and dimensions of practice (consequences) (Glock \& Stark in Ancok and Suroso, 2004: 77-78).

a. The Dimension of Belief (Ideological)

This dimension of belief contains expectations where religious people hold fast to certain theological views and acknowledge the truth of the doctrines of the theological views.

b. The Dimensions of Worship (Ritualistic)

The dimensions of worship are aspects that measure the extent to which a person performs his ritual obligations in the teachings adopted. For example; go to places of worship, pray privately, fast, and so on. The dimension of worship is more about the worship, obedience, and things that a person does to show his commitment to the religion he has adopted.

c. The Dimension of Appreciation (Experiential) 
The dimension of appreciation refers more to religious experiences, feelings, perceptions, and sensations experienced or defined by a person or religious group.

d. The Dimension of Religious Knowledge (Intellectual)

This dimension refers to the hope that religious people have at least a minimum amount of knowledge about the basics of beliefs, scriptures, and traditions.

e. The Dimension of Practice (Consequences)

This dimension refers more to the identification of the effects of religious beliefs, practices, customs, and knowledge in a day-to-day basis. This dimension relates to the activities of religious adherents to realize the teachings and more directed to the human relationship with each other in daily life that is based on the ethics and spirituality of the religion they profess.

All the five dimensions explained above can be used as a reference for the readers to see whether the religious values are expressed or embedded in literary works. One form of literary works that often contain religious values is a novel.

Novel is a story in the form of prose on a broader scale (Sumardjo, 1997: 30). A broader scale here can mean a story with a complex plot, a diverse story atmosphere and a variety of story settings as well. In line with Sumardjo, Sayuti (2000) also said that novel is a work in the form of prose, which generally contains forty-five thousand words or more. In the sense of the length of a novel, it makes a special opportunity to question characters in a journey. Kosasih (2012:60) states that a novel is an imaginative work that tells the whole side of the problematics in the life of a person or several figures.

Today there are many novels with religious themes that are selling well and can be accepted by the public. It might be so because, in addition to providing insight and entertaining, these novels can also increase the confidence and motivation of their readers to be even better in carrying out their obedience in worshiping God the Almighty. One novel loaded with religious values is Entrok written by Okky Madasari.

Entrok tells about religiosity or a belief that is believed, implemented, and has rules that must be carried out and may not be violated by its adherents or, in other words, there are dimensions of religiosity that the author wishes to convey through a character named Marni.

Set in the 1950s in a village called Singget, Entrok tells about the journey and struggle of life of an illiterate Javanese woman named Marni, who still closely holds the teachings of her ancestors by asking all her hopes to the ancestors called Gusti Mbah Ibu Bumi Bapa Kuasa (literally means Mother Earth, Father of Power). She has never learnt or known any religion and God, all she knows is everything that happens is at the will of Gusti Mbah Ibu Bumi Bapa Kuasa, through the offerings that are always done routinely every time she is asking for hope. The novel also tells about the struggle to get entrok when Marni began to grow up and her chest began to mringkili (stroking), her struggle for a better life by toiling out for penny after penny for life. What is important for Marni in seeking the fortune, as long as she does not steal, rob, cheat or kill people, means that she has not committed a sin.

Conflicts occur when she has a child named Rahayu who increasingly understands the true religion, understands who her god is and strongly opposes her mother's teachings. Conflicts also occur among people who say Marni's way of life is wrong, accusing her to be a communist. Things got worse when her husband Teja died in an accident, and her daughter Rahayu, who chose to go far away to study and work in Yogyakarta, resulted in her business going bankrupt.

Marni and Rahayu are two generations who can never understand each other. They live in each other's thoughts without a meeting point. Until finally they realize there is actually a point of contact in their lives: they both are victims of those who have power, they both are against the weapons.

This Entrok novel is selected because of the religious values contained therein that need to be described, analyzed and interpreted so as to spread out the message of religious values conveyed by the author through this novel through Marni who tightly holds her belief. She expresses the implementation of worship by asking Gusti Mbah Bumi Bapa Kuasa in the middle of the night under a tree kneeling and closing her eyes, asking for all expectations through the use of offerings in the rituals as a form of gratitude for all that was given by Gusti Mbah Ibu Bumi Bapa Kuasa.

As Suroso (2011) argues in his article "Kepriyayian Tokoh Dalam Novel Warna Lokal Jawa dan Sumbangannya Dalam Pengembangan Karakter Bangsa", reading the characters presented by the author in the novel is reading the author's ideology and philosophy conveyed to the reader. In the sense of literature, it is a funnel of philosophy in which the conceptions of the mind, the author's ideas, are conveyed through the main character who carries the message. That is why researchers are interested in conducting a study on the values of religiosity in the novel.

\section{RESEARCH METHOD}

This study was a descriptive qualitative research. Qualitative research is a type of research in which researchers are highly dependent on information from the objects/participants; the data consist mainly of words/texts from the objects/ participants; explaining and analyzing data are conducted subjectively (Creswell, 2008:46). While the descriptive method itself is a procedure of solving research problems by describing the state of the object under study as it is, based on the facts that occur (Surackhmad, 1990:139).

This study used the hermeneutic approach. Ricouer (in Sumaryono, 1999:107) says that hermeneutics is a theory of interpretation or the operation of understanding in relation to text". Basically deals with language, hermeneutics is "the science or expertise of interpreting novels and language expressions in a broader sense according to their intentions 
(Teew, 1984:123). The data of this study are sentences and quotations containing the religious values taken from Entrok, a novel by Okky Madasari. Data were collected through reading and writing.

\section{RESULTS AND DISCUSSION}

Based on the identification and analysis the values of religiosity of the woman named Marni the novel, the results can be presented as follows.

\section{Dimension of Belief (Ideological)}

The dimension of belief is found especially in the figure of Marni who tightly holds the teachings of her ancestors, i.e. by asking for all expectations to the figure she believes in, Gusti Mbah Ibu Bumi Bapa Kuasa, as seen in the following datum:

(1) Nduk, terserah apa penginmu. Yang penting, coba nyuwun sama Mbah Ibu Bumi Bapa Kuasa. Semua kejadian hanya terjadi kalau Dia menginginkan." Pg. 42

From the quotation, it is clear that Marni is very tightly holding her worshiping beliefs and asking all hope to Gusti Mbah Ibu Bumi Bapa Kuasa, Marni believes her teachings since she was taught by her mother since childhood, that all who govern, all who give and do not give us what we want is Gusti Mbah Ibu Bumi Bapa Kuasa. This is also supported in the following datum:

(2) Sampai setua ini, sampai punya anak sebesar kamu, Nduk, aku tidak pernah tahu Gusti Allah. Mbah Ibu Bumi yang selalu membantuku. Mbah Ibu Bumi yang memberiku semua ini. Apanya yang salah?” Pg. 59

The quotation above also explains that the figure of Marni very tightly holds her teachings, strongly believes that the teachings are the most correct. Gusti Mbah Bumi Bapa Kuasa is the one who gives everything and fulfills all hopes, and this was also the belief held by her mother. The belief that was also held by Rahayu when she was a child and did not yet know the true teaching, that is Allah.

The conviction that all hope is only upon the will of Mbah Bumi Bapa Kuasa is also seen in the quotations below:

(3) Sungguh atas pertolongan Mbah Ibu Bumi Bapa Kuasa semua yang kudapatkan saat ini. Memang aku mendapatkan daun dewandaru dari Pesarean Gunung Kawi. Tapi kan daun itu hanya mau jatuh kalau Mbah Ibu Bumi Bapa Kuasa menjatuhkannya. Aku juga kerja keras, memeras keringat, mengelilingi Pasar Ngranget dan dari rumah ke rumah di desa-desa. Semua kulakukan hanya agar aku dan keluargaku bisa makan, tidak merepotkan orang lain, dan punya kemuliaan dalam hidup. Lah kok yo masih ada yang bilang aku dosa. Yang dosa itu ya orang kayak Mali itu, seharian tidur di langgar, istri dan empat anaknya tiap hari kelaparan. Pg. 99

(4) Dia bilang aku ini dosa. Dia bilang aku ini syirik. Dia bilang aku penyembah leluhur. Lho... lha wong aku sejak kecil diajari orangtuaku nyembah leluhur kok tidak boleh. Lah buktinya setiap aku minta ke leluhur, lewat tumpeng dan panggang yang harganya tidak seberapa itu, semua yang kuminta kudapatkan. Dia bilang hanya Gusti Allah yang boleh disembah. Lha iya, tapi wong aku tahu Gusti Allah ya baru-baru ini saja. Lha gimana mau nyuwun kalau kenal saja belum. Pg. 100-101

From the quotation (3) it is clear that Marni believes strongly in her teachings, she believes that only Mbah Ibu Bumi Bapa Kuasa granted all her wishes, it is seen in the sentence stating that she got the dewandaru (Eugenia uniflora) leaves that fell on the ground for her and not for anyone else. It is the leaves that she then sells in the market believed to give prosperity to her life at the will of $M b a h$ Bumi Bapa Kuasa. This conviction is also supported in the quotation (4) in the phrase "Lah buktinya setiap aku minta ke leluhur, lewat tumpeng dan panggang yang harganya tidak seberapa itu, semua yang kuminta kudapatkan."

In accordance with the concept of the ideological dimension according to Glock \& Stark (Ancok \& Suroso, 2004), it contains expectations where religious people hold fast to certain theological views and acknowledge the truth of the doctrines of the theological view. Quotation (4) explains that there will be an ideological dimension in Marni, who holds and considers everything she does (asking Mbah Ibu Bumi Bapa Kuasa) to be true and not unmistakable teachings, let alone syirik (believing in gods other than Allah the Almighty) as Rahayu accused of her.

\section{Dimensions of Worship (Ritualistic)}

The dimension of worship of Marni in this novel is found in the following quotations.

"Simbok menyuruhku memejamkan mata, lalu mengucapkan permintaanku dalam hati. Simbok sendiri juga memejamkan mata. Dengan mata saling terpejam, kami diam beberapa saat. Saat itu angin berhenti berembus, jangkrik dan katak menghentikan semua ocehannya.

Aku sebenarnya tidak tahu apa yang harus kulakukan. Sekadar mengikuti perintah Simbok, kuucapkan permintaanku dalam hati, "Gusti Mbah Ibu Bumi Bapa Kuasa, berkatilah usahaku. Aku mau punya uang, memiliki seperti dimiliki Nyai Wedana. Biar nggak pernah ngerepoti orang lain." Permintaan itu kuulangi terus, sampai Simbok menyentuh bahuku dan mengajakku masuk rumah. Pg. 42-43 
The data in the quotation (5) explains about the process of how Marni and her mother performed the worship or rituals as a way of asking for hope from Mbah Ibu Bumi Bapa Kuasa who has all the will to grant all her wishes. This ritual was carried out by Marni and her mother when Marni planned to start a business going around the village, from house to house in Singget so that she could have money to be able to live independently and not bother the others. Simbok believes, by closing his eyes, then asking for what we want, then Mbah Ibu Bumi Bapa Kuasa will grant it. Although Marni did not understand what Simbok was doing, she continued to perform the ritual with confidence. The ways that they do it very clearly illustrate the dimensions of worship (ritualistic) regarding worship behavior, obedience and things done by someone to show their commitment to the religion that was held, and that's what Marni and Simbok did. The way they did it clearly illustrates the dimension of worship (ritual). The next quotation also includes data related to the dimension of worship, as seen below:

(6) Ibu punya kebiasan aneh, yang berbeda dibanding orang-orang lain. Setiap hari dia selalu keluar rumah pada tengah malam, lalu duduk sendirian di bangku di bawah pohon asem di depan rumah. Ibu duduk tenang, memejamkan mata, lalu komat-kamit.

Dulu sekali, aku juga melakukan apa yang Ibu lakukan. Ibu membangunkanku, lalu kami berdua duduk di bawah pohon asem. Kata Ibu itu namanya berdoa, tirakat. Ibu mengajariku untuk nyuwun. Katanya, semua yang ada di dunia milik Mbah Ibu Bumi Bapa Kuasa. Dialah yang punya kuasa untuk memberikan atau tidak memberikan yang kita inginkan. "Nyuwun supaya jadi orang pintar. Bisa jadi pegawai," kata Ibu.

Aku mengikuti semua gerak-gerik Ibu. Mulai dari sikapnya yang duduk dengan punggung tegak, mata terpejam, lalu mulut komat-kamit mengucapkan permintaan. Kuиcapkan berkali-kali kata yang diajarkan Ibu, "Mbah Ibu Bumi Bapa Kuasa, berilah saya kepintaran. Paling pintar di sekolah. iar nanti bisa jadi pegawai." Pg.55-56

Aku, Bapak, dan Tonah tahu, tumpeng dan panggang yang dimakan saat selamatan bukan satu-satunya yang dimasak setiap hari kelahiran. Ibu menyimpan satu tumpeng dan panggang lagi lengkap dengan ubo rampe-nya di kamarnya. Ditaruh di meja samping lemari kaca, beralas baki, ditemani sebatang lilin. Kata Ibu, tumpeng dan panggang itu dikirim untuk Mbah Ibu Bumi Bapa Kuasa. Keesokan harinya, Ibu akan mengeluarkan tumpeng dan panggang itu. Tonah akan memasaknya kembali untuk kami makan semua .Pg. 56

"Malam pun datang. Senyap dan dingin. Pesarean itu tampak seperti makam pada umumnya, meskipun ada puluhan orang di situ. Mereka duduk di seluruh areal makam menghadap makam Eyang Sujo dan Eyang Jugo. Tak ada suara apapun, bahkan helaan nafas pun terdengar. Masing-masing orang tengah melakukan perjalanan batin ke alam antah-berantah menemui dewa pemberi berkah. Pg. 97

Following the definition of worship that has been discussed, the data above show worship conducted by Marni and Rahayu to Mbah Ibu Bumi Bapa Kuasa by sitting under a tamarind tree with the back of his back, closing his eyes and then mumbling for a request. Similar to the form of worship in the previous quotation, Marni's compilation will make an effort to sell around the village.

In quotation (8) we see that Marni compiles to perform rituals in pesarean (graveyard). This method is a dimension of worship in the form of performing rituals in her beliefs. This ritual was performed by Marni in Pesarean Eyang Sujo and Eyang Jugo. The difference is the different rituals Marni compiles asking for hope from Mbah Ibu Bumi Bapa Kuasa, while in pesarean, Marni asks for Eyang Sujo and Eyang Jugo to ask for the smoothness and shape given by dewandaru leaves that can help her lap. These leaves provide a smooth fortune to the owner.

This method is a dimension of worship by performing rituals in accordance to her beliefs. Similarly, in quotation (7) Marni performed rituals of worship in the form of making sesajen tumpeng and roasted chicken offerings accompanied by ubo rampe which must be eaten together the next day by Marni, Tedja (Marni's husband) and Rahayu, their daugher. This sesajen tumpeng is a tool and a condition that must be present in performing worship, both when showing gratefulness and when celebrating birthdays in her family

\section{Dimension of Appreciation (Experiential)}

The dimension of appreciation refers more to religious experiences, feelings, perceptions and sensations experienced or defined by a person or a religious group. Examples of dimension of appreciation in this novel can be seen in the following quotation.

(9) Gusti! Mbah Ibu Bumi Bapa Kuasa! Inikah jawaban atas seтиа doaku? Inikah balasanMu atas sesajen yang kubuat setiap hari kelahiran anakku? Aku begitu bersemangat. Pg.268

In the quotation (9) it is a form of appreciation or religious experience, as well as the feelings felt by Marni for what she got after years of rituals of giving offerings to Mbah Ibu Bumi Bapa Kuasa. Marni believes that giving offerings and sesajen for the birthdate of her child (Rahayu) will have a good influence on her life and comfortable living. The good influence and smoothness of Marni felt when Rahayu who had been in prison for being suspected as influencing and inciting residents to fight against contractors who tried to seize their land would soon be 
released from prison within the coming month. The incident occurred when Rahayu was in the village in Magelang while helping Pak Kyai Hasbi and the other residents whose land would be dredged by a contractor and were considered to have violated the law, so she was put in jail.

\section{Dimensions of Religious Knowledge (Intellectual)}

This dimension refers to the hope that religious people have at least a minimum amount of knowledge concerning the basics of their religious beliefs, scriptures and traditions. Data that refer to this dimension can be seen in the following datum.

(10) Ibu Marah. "Aku nyuwun pada Mbah Bumi Bapa Kuasa sejak lahir. Aku tidak mengganggu orang lain. Dosa apa yang kulakukan?” Pg. 59

Quotation (10) explains about the basics of beliefs that Marni professes. The basics of belief is explained by Marni when she is having a debate with Rahayu about the right way to ask, namely by praying five times a day to Gusti Allah as what is believed by Rahayu and Mr.Waji. Marni explains that the belief that she holds is right and there is nothing wrong with it. Because even since her childhood, Marni had been taught by her mother that Mbah Ibu Bumi Bapa Kuasa adalah was the only place to ask for anything. There is no other place to ask, there is no other Giver of Kuasa than Mbah Ibu Bumi Bapa Kuasa.

\section{Dimension of Practice (Consequences)}

This dimension refers more to the identification of the effects of religious beliefs, practices, and knowledge from day to day. This dimension relates to the activities of religious adherents to realize the teachings and more directed to the human relationship with each other in daily life that is based on the ethics and spirituality of the religion they profess. Data on this dimension of practice can be seen in the following datum.

(11) Sayangnya tidak ada buruh perempuan di sini, betapapun ingin aku mengupahi mereka dengan uang sebesar buruh laki-laki. Upah yang besarnya sama, tidak lebih kecil hanya karena dia perempuan, lebih-lebih hanya diupahi dengan telo. Tapi tak ada perempuan yang ikut menebang tebu. Tebu hanya menjadi jatah buruh-buruh laki-laki. Bagian buruh perempuan hanya nderep atau mbethot kacang. Tapi coba tanya perempuan-perempuan itu berapa upah yang mereka dapat. Paling-paling tak lebih daripada tiga ratus sehari. Sayangnya, aku tidak menanam padi atau kacang. Kalau Mbah Ibu Bumi Bapa Kuasa mengizinkan, semoga rezekiku dilancarkan, aku punya duit untuk membeli tanah lagi yang akan kutanami padi dan kacang. Akan kupekerjakan perempuan-perempuan itu dan kuberi upah tak kurang daripada yang diterima suami-suami mereka.

Sudah tiga hari lalu tebuku ditebang. Uang panen sudah kusisihkan 250.000 untuk sumbangan kampanye. Pamong desa mengambilnya tadi pagi. Dia mengingatkanku untuk datang pada kampanye bulan depan. Aku mengiyakan. Pg. 103

Based on quotation (11) it is clear that the elements of the dimension of practice states the consequences or realization of the teachings believed by Marni. This can be seen in Marni's relationship with the surrounding community, in this case her empathy with the female workers who do not get work for cutting down the sugar canes, but can only do nderep (harvesting rice) and mbethot (revoking) beans, for which they are paid lower wages than male workers. Marni is eager to be able to employ them later if she is given a better fortune and able to buy more land for plantation. In addition, the figure of Marni in this novel is a person who cares for others, which is marked by her voluntary efforts to set aside some money for political campaign activities in her village.

\section{CONCLUSION}

Based on the analysis above, this research shows some points related to the values of religiosity in Entrok novel. The novel contained five dimensions of religious values as mentioned by Glock \& Stark from the figure of the main character Marni, i.e.: 1) the value of belief (ideological); 2) the value of worship (ritualistic); 3) the value of appreciation (experiential); 4) the value of religious knowledge (intellectual); and 5) the value of practice (consequences), all of which are reflected in the form of here belief in Mbah Ibu Bumi Bapa Kuasa. This explains that Entrok is indeed a novel full of religious values and can be used as reading material that can add insights, knowledge and increase the confidence of the readers.

\section{REFERENCES}

Atmosuwito, S. (1989). Perihal Sastra dan Religiusitas dalam Sastra. Bandung: Sinar Baru.

Ancok, D. \& Suroso, F.N. (2004). Psikologi Islami: Solusi Islam atas Problem-problem Psikologi. Cetakan 4. Yogyakarta: Pustaka Pelajar.

Ajidarma, S. W. (2010). Trilogi Insiden; Saksi Mata; Jazz, Parfum \& Indisen; Ketika Jurnalisme Dibungkam, Sastra Harus Bicara. Yogyakarta: Bentang Pustaka.

Creswell, J.W. (2008). Research Design, Pendekatan Kualitatif, Kuantitatif, dan Mixed, Edisi Ketiga. Bandung: Pustaka Pelajar.

Faruk. (2012). Pengantar Sosiologi Sastra, dari Strukturalisme Genetik sampai Post-Modernisme (Cetakan Kedua). Yogyakarta: Pustaka Pelajar.

Kosasih, E. (2012). Dasar-dasar Keterampilan Bersastra. Bandung: Yrama Widya.

Mangunwijaya, Y.B. 1988. Sastra dan Religiusitas. Yogyakarta: Kanisius. Mohammad, G. (1969). "Posisi Sastra Keagamaan Kita Dewasa Ini." Dalam Antologi Esei tentang Persoalan-Persoalan Sastra. Satyagraha Hoerip. 1969. Jakarta: Sinar kasih.

Putriani, Hani Yolanda. (2015). Pola Perilaku Konsumsi Islami Mahasiswa Muslim Fakultas Ekonomi dan Bisnis Universitas Airlangga Ditinjau Dari Aspek Religiusitas. Jurnal JESTT, Vol. 2, No. 7 Juli 2015. Surabaya: Universitas Airlangga, 2015.

Sayuti, S.A. 2000. Berkenalan dengan Prosa Fiksi. Yogyakarta: Gama Media. 
Sharififar, M. (2010). Applicability of Newmark's Procedures to Translation of Relgious Cultural Elements from English into Persian. Kerman: Shahid Bahonar University of Kerman.

Sayuti, S.A. (1999). "Sastra dalam Perspektif Pembelajaran: Beberapa Catatan". Makalah pada Pertemuan Ilmiah Nasional (Pilnas) HISKI, 18-20 Oktober 1999.

Semi. (1988). Anatomi Sastra. Padang: Angkasa Raya.

Sumaryono, E. (1999). "Hermeneutik: Sebuah Metode Filsafat". (first edition). Yogyakarta: Penerbit Kanisius.

Pustaka Jaya.
Sumardjo, J. \& Saini K.M. (1997). Apresiasi Kesusastraan. Jakarta: Gramedia.

Suroso. (2011). Kepriyayian Tokoh dalam Novel Warna Lokal Jawa dan Sumbangannya dalam Pengembangan Bangsa. Yogyakarta. Journal LITERA. Vol. 10, No. 2. 2011. https://journal.uny.ac.id/index.php/litera/article/view/1162

Surakhmad, W. (1990). Pengantar Penelitian Ilmiah. Bandung: Tarsito.

Teeuw, A. (1984). Karya Sastra sebagai Struktur: Strukturalisme dalam Sastra dan Ilmu Sastra: Pengantar Teori Sastra. Jakarta: 